\title{
Carcinoma Mucoepidermoide de Glândulas Salivares Menores
}

\author{
Mucoepidermoid Carcinoma of Minor Salivary Glands
}

\author{
Paulo Tinoco*, José Carlos Oliveira Pereira**, Rodolfo Caldas Lourenço Filbo***, \\ Thiego Silveira Cajubá Brito $* * * *$, Betina Mameri Pereira $* * * * *$, Vânia Lúcia Carrara $* * * * *$, \\ Sueliana Marta F. Godoy $* * * * *$.
}

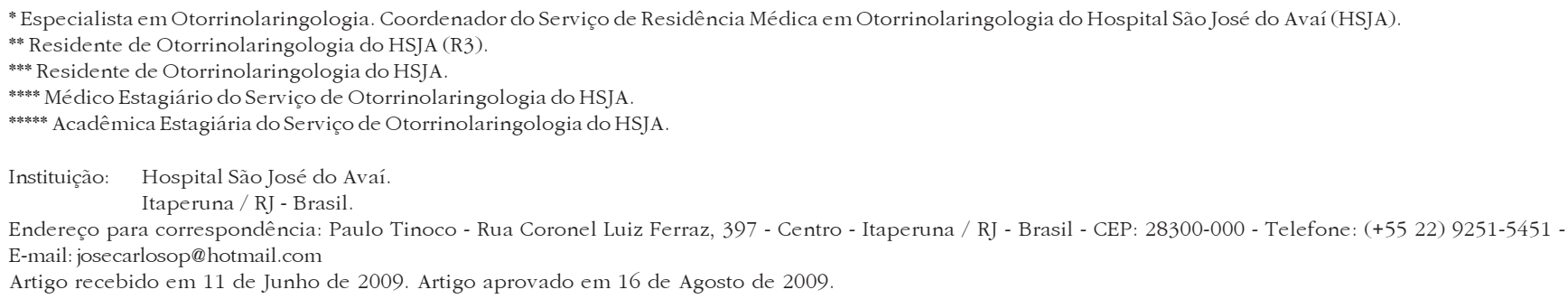

\section{RESUMO}

Introdução:

Objetivo:

Relato do Caso:

Comentários Finais:

Palavras-chave:

\section{SUMMARY}

Introduction:

Objective:

Case Report:

Final Comments:

Keywords:
Os carcinomas mucoepidermoides (CME) representam cerca de 5\% de todos os tumores das glândulas salivares. Trata-se de uma lesão agressiva e deve ser considerada como hipótese de diagnóstico em lesões proliferativas da mucosa oral. O diagnóstico precoce e o correto manejo dessa neoplasia são fatores determinantes do prognóstico. Ressecção local ampla e eventualmente a radioterapia pósoperatória são o tratamento de escolha.

Relatar o caso de uma paciente com carcinoma mucoepidermoide de cavidade oral, exteriorandose pela boca, sendo submetida a exérese cirúrgica e radioterapia, evoluindo para óbito no quarto mês do início do tratamento.

CT, 47 anos, branca, foi encaminhada ao serviço de ORL do HSJA após episódio de sangramento importante em cavidade oral. Relatou o surgimento de uma massa com crescimento rápido e expansivo em topografia de fossa canina há +/- 06 meses, associado a emagrecimento de $10 \mathrm{~kg}$. Paciente desidratada, hipocorada, apresentando tumoração pediculada de $+/-06 \mathrm{~cm}$, consistência firme, indolor à palpação, sangrante. Etilista e tabagista crônica. Linfonodos cervicais não palpáveis. Diante do caso optou por fazer a ressecção cirúrgica do tumor e realizar o exame histopatológico que confirmou carcinoma mucoepidermoide de glândulas salivares menores. A paciente foi encaminhada ao serviço de radioterapia; porém, abandonou o tratamento e evoluiu com óbito 4 meses após.

Neste caso, o crescimento rápido e agressivo da lesão, o tamanho do tumor e o abandono do tratamento proposto foi determinante no prognóstico da paciente.

tumor mucoepidermoide, glândulas salivares menores, boca.

The Mucoepidermoid Carcinomas (MEC) represent about 5\% of all tumors in the salivary glands. It is an aggressive lesion and must be considered as a diagnosis hypothesis in the oral mucosa proliferative lesions. The early diagnosis and the correct management of this neoplasm are key factors for the prognosis. Wide local resection and eventually postoperative radiotherapy is the choice treatment. To report the case of a patient with mucoepidermoid carcinoma of oral cavity, exteriorizing through the mouth and being submitted to surgical exeresis and radiotherapy that evolved to death on the fourth month from beginning of the treatment.

CT, 47 years old, white woman was forwarded to the ORL service of the HSJA after a critical bleeding episode in oral cavity. She reported the appearing of a mass with fast and expansive growth in a topography of canine fossa for $+/-06$ months, associated to the loss of $10 \mathrm{~kg}$. Patient dehydrated, pale with pediculated tumoration of $+/-06 \mathrm{~cm}$, firm consistency, painless upon palpation and bleeding. Chronic alcoholic and smoker. Non-palpable cervical lymph nodes. Faced with the case we opted for a surgical resection of the tumor and the performance of histopathological exam that confirmed mucoepidermoid carcinoma of minor salivary glands. The patient was sent to the radiotherapy service; but she abandoned the treatment and evolved with death 4 months after.

In this case, the fast and aggressive growth of the lesion, the size of the tumor and the abandonment of the proposed treatment was determinant for the patient's prognosis.

mucoepidermoid tumor, minor salivary glands, mouth. 


\section{INTRODUÇÃO}

Os carcinomas mucoepidermoides (CME) representam cerca de $5 \%$ de todos os tumores das glândulas salivares. Acometem as glândulas salivares maiores e menores intraorais em mais de $90 \%$ dos casos (1,2). Nas glândulas salivares menores, acomete principalmente o palato e soalho de boca, em geral na quinta década da vida, e com discreto predomínio no sexo feminino. Histologicamente, os carcinomas mucoepidermoides têm sido classificados em três graus de malignidade (baixo, intermediário e alto grau), e esta subdivisão tem se mostrado útil no estabelecimento da terapêutica e no prognóstico destes tumores $(3,4,5)$. O diagnóstico precoce e o correto manejo dessa enfermidade são fatores determinantes do prognóstico. Trata-se de uma lesão agressiva e deve ser considerada como hipótese de diagnóstico em lesões proliferativas da mucosa bucal, mesmo quando sua aparência clínica não sugerir malignidade.

\section{Relato do Caso}

CT, 47 anos, branca, casada, dona de casa, natural e moradora de Italva/RJ, foi encaminhada a o serviço de ORL do HSJA após episódio de sangramento importante em cavidade oral. Relatou o surgimento de uma massa com crescimento rápido e expansivo em topografia de fossa canina há +/- 06 meses, associado a emagrecimento de 10 kg. Paciente lúcida, orientada, estado geral regular, desidratada $(++/+4)$, hipocorada $(++/+4)$, apresentando tumoração pediculada de $+/-06 \mathrm{~cm}$ (Figura1), consistência firme, indolor à palpação, sangrante; linfonodos cervicais não palpáveis.Etilista e tabagista crônica, sem história familiar para neoplasia. Diante do caso optou por fazer a ressecção cirúrgica do tumor (Figura 2) e realizar o exame histopatológico que confirmou carcinoma mucoepidermoide de glândulas salivares menores de grau intermediário (Figura 3). A paciente foi encaminhada ao serviço de radioterapia; porém, abandonou o tratamento e evoluiu com óbito 4 meses após.

\section{DISCUSSÃO}

Carcinomas mucoepidermoides (CME) são tumores malignos originados de ductos excretores de estruturas glandulares, que acometem as glândulas salivares maiores e menores intra-orais em mais de $90 \%$ dos casos (1,2). CME também pode ocorrer em glândulas de revestimento dos seios maxilares, glândulas lacrimais, orofaringe, nasofaringe, laringe, pregas vocais, traqueia e pulmões (2).

A etiopatogenia do CME é desconhecida, todavia, assim como os demais cânceres, a lesão resulta de altera-

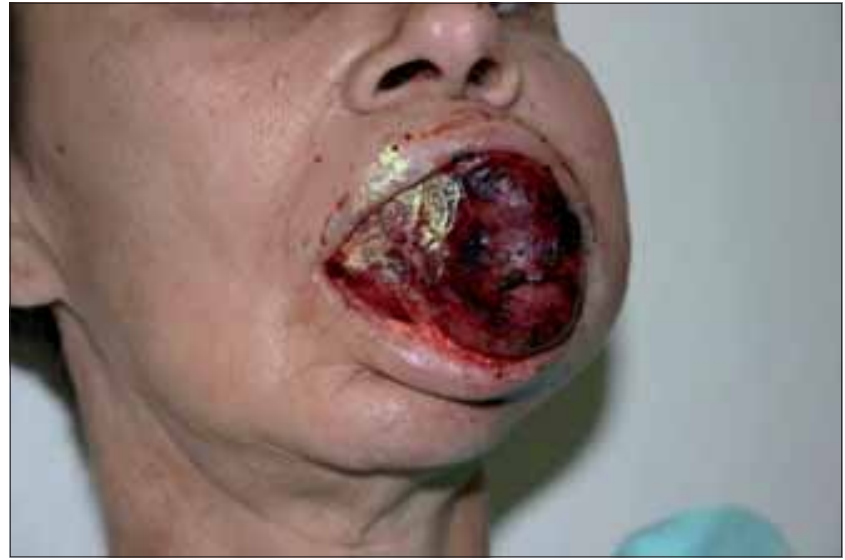

Figura 1. Tumoração pediculada em cavidade oral.

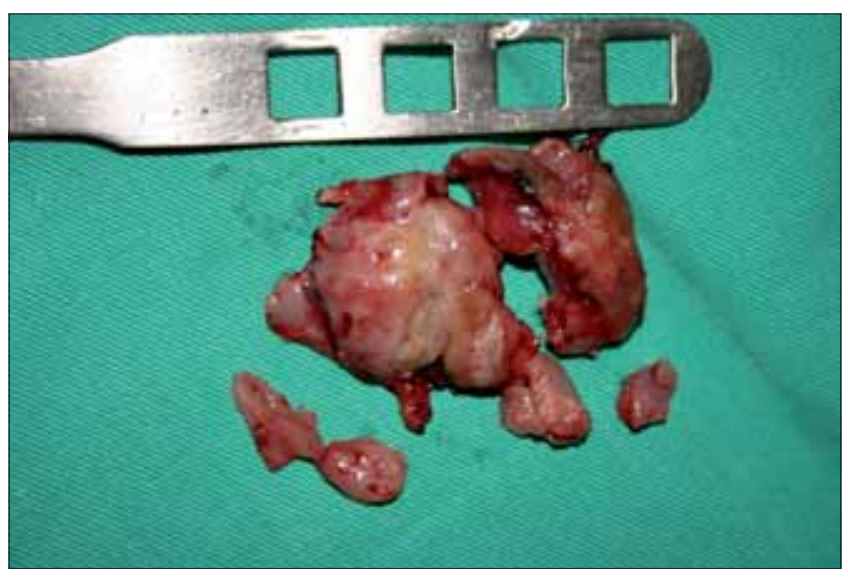

Figura 2. Peça cirúrgica.

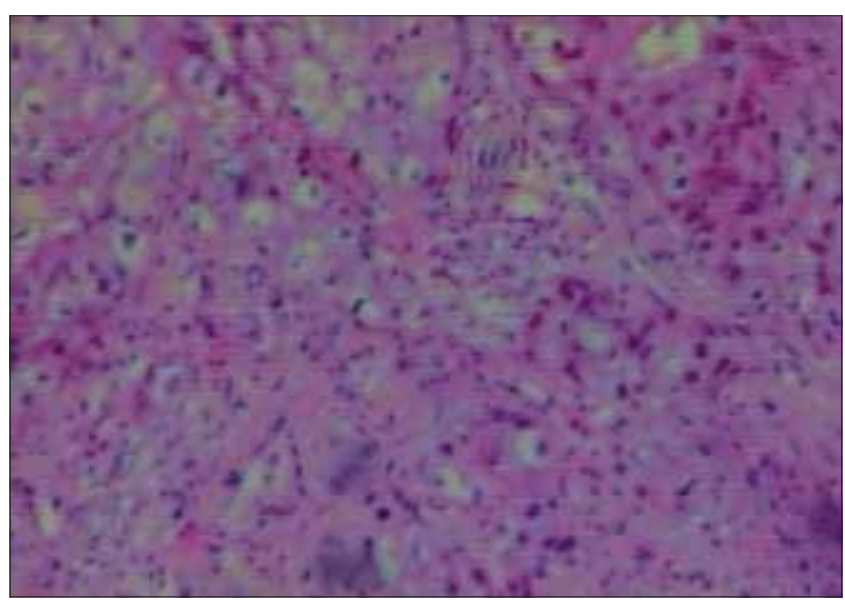

Figura 3. Exame de microscopia óptica do carcinoma mucoepidermoide de glândulas salivares menores. Microscopia (HE 100 x).

ções genéticas, sendo que os proto-oncogenes e os genes supressores de tumor, quando alterados, desenvolvem um papel importante em sua patogênese. Como fatores predisponentes têm-se exposição à radiação ionizante, RT 
prévia, refino de níquel, solventes químicos, couro, serragem, formaldeído, poluição (9). As características histopatológicas doCMEsão: presença de células escamosas, células produtoras de muco e células do tipo intermediário. O tipo celular predominante e sua configuração variam entre os tumores e dentro da mesma massa tumoral.

Clinicamente, o CME pode apresentar-se como lesão de cor variando do azul ao vermelho ou púrpura. As lesões da mucosa bucal, assoalho de boca, lábios e região retromolar apresentam-se como massas submucosas assintomáticas, enquanto lesões na língua são frequentemente dolorosas. Os fatores relacionados ao prognóstico do CME são: tamanho da lesão primária no momento da cirurgia, graduação histológica do tumor e presença de metástases.

Ressecção local ampla, associada ou não a esvaziamento cervical, e eventualmente a radioterapia pós-operatória, é o tratamento de escolha para os carcinomas mucoepidermoides $(1,5,6,7,8)$. A ressecção de estruturas adjacentes está indicada em casos onde exista comprometimento detectado previamente ou durante a cirurgia.

\section{COMENTÁRIOS FINAIS}

Estes tumores apresentam diferentes comportamentos biológicos conforme o grau de diferenciação histológico, tamanho da lesão e presença de metástases; o diagnóstico precoce e o correto manejo são fatores determinantes do prognóstico.

Neste caso, o crescimento rápido e agressivo da lesão, o tamanho do tumor foi determinante no prognóstico da paciente.

\section{REFERENCIAS BIBLIOGRÁFICAS}

1. Ellis GL, Auclair PL, Gnepp DR. Surgical Pathology of the salivary glands. Major Problems in Pathology Series. Volume 25. Philadelphia: WB Saunders Company; 1991.
2. Ellis GL, Auclair PL. Tumors of the Salivary Glands. In: Armed Forces Institute of Pathology. Atlas of Tumor Pathology. $3^{\text {rd }}$ Series, Fascicle 17. Washington; 1996.

3. Auclair PL, Goode RK, Ellis GL. Mucoepidermoid carcinoma of intraoral salivary glands. Cancer. 1992, 69:202130 .

4. Cardoso WP, Denardin OV, Rapoport A, Araújo VC, Carvalho MB. Proliferating cell nuclear antigen expression in mucoepidermoid carcinoma of salivary glands. São Paulo Med J. 2000, 118:69-74.

5. Goode RK, Auclair PL, Ellis GL. Mucoepidermoid carcinoma of the major salivary glands: clinical and histopathologic analysis of 234 cases with evaluation of grading criteria. Cancer. 1998, 82:1217-24.

6. Brandwein MS, Ivanov K, Wallace DI, Hille JJ, Wang B, Fahmy A, Bodian C, Urken ML, Gnepp DR, Huvos A, Lumerman H, Mills SE. Mucoepidermoid carcinoma: a clinicopathologic study of 80 patients with special reference to histological grading. Am J Surg Pathol. 2001, 25:835-45.

7. Plambeck K, Friedrich RE, Bahlo M, Bartel-Friedrich S, Klapdor R. TNM staging, histopathological grading, and tumor-associated antigens in patients with a history of mucoepidermoid carcinoma of the salivary glands. Anticancer Res. 1999, 19:2397-404.

8. Spiro RH, Huvos AG, Berk R, Strong EW. Mucoepidermoid carcinoma of salivary gland origin: a clinicopathologic study of 367 cases. Am J Surg. 1978, 136:461-8.

9. Calderón-Garcidueñas L, Delgado R, CalderónGarcidueñas A, Meneses A, Ruiz LM, Garza J, Acuna H, Villarreal-Calderón A, Raab-Traub N, Devlin R. Malignant neoplasms of the nasal cavity and paranasal sinuses: A series of 256 patients in México City and Monterrey. Is air pollution the missing link? Otolaryngol Head Neck Surg. Apr. 2000, 122:499-508. 